DOI: $10.17148 / I A R J S E T .2021 .8880$

\title{
Assessment of per se performance of chilli (Capsicum annuum L.) hybrids in Salem District of Tamil Nadu
}

\author{
Malathi, G' ${ }^{1}$ R.Vijayan ${ }^{2}$, M.Vijayakumar ${ }^{3}$, P.Kohila ${ }^{4}$ and Sriram, $\mathbf{N}^{5}$ \\ ${ }^{1}$ Assistant Professor (Hort.), Krishi Vigyan Kendra, Sandhiyur, Salem, Tamil Nadu \\ ${ }^{2}$ Assistant Professor (SST), Krishi Vigyan Kendra, Sandhiyur, Salem, Tamil Nadu \\ ${ }^{3}$ Associate Professor (Agron.), Krishi Vigyan Kendra, Sandhiyur, Salem, Tamil Nadu \\ ${ }^{4}$ Assistant Professor (V\&AS), Krishi Vigyan Kendra, Sandhiyur, Salem, Tamil Nadu \\ ${ }^{5}$ Associate Professor (Extension), Krishi Vigyan Kendra, Vriddachalam, Cuddalore, Tamil Nadu
}

\begin{abstract}
Chilli is an important spice cum vegetable crop which is grown throughout India. India is the world's largest producer, consumer and exporter of chillies in the world. The important states of chilli production are Andhra Pradesh, Orissa, Maharashtra, West Bengal, Karnataka, Rajasthan and Tamil Nadu. In Salem district, area under chilli cultivation is around 1089 ha in the year 2013-14. Among 20 blocks of Salem district, Kolathur block is well known for chilli cultivation in Salem District. An investigation is needed to assess the performance of high pungent chilli hybrids in Salem district. Hence, this investigation had been carried out to assess the per se performance of high pungent chilli hybrids in Salem district. A field experiment was conducted as an on farm trial in five different locations of Salem district during Kharif season of 2017 in chilli using hybrids Arka Harita and TNAU Chilli Hybrid CO 1 with Sierra Hybrid of Mahyco (drought and powdery mildew tolerant hybrid with medium pungency fruits of more than $10 \mathrm{~cm}$ long and diameter of 1.1 to $1.3 \mathrm{~cm}$ ) as check hybrid. Arka Harita showed profuse flowering and continuous fruit setting character with tolerance to powdery mildew and TNAU Chilli Hybrid CO 1 is moderately resistant to fruit rot disease. Both are high pungent high yielding hybrids. The results showed that TNAU chilli hybrid CO 1 recorded highest individual fruit weight of $30 \mathrm{~g}$ followed by Arka Harita with individual fruit weight of $28 \mathrm{~g}$. The check hybrid Sierra recorded lesser fruit weight of 23g. Regarding yield attribute, Arka Harita recorded highest yield per hectare (28.2t/ha) followed by TNAU Chilli Hybrid CO1 (26t/ha) which might be due to the more number of fruits per plant in Arka Harita hybrid. Regarding BC ratio, Arka Harita recorded 2.13 as against 1.97 in TNAU Chilli hybrid CO 1. Least BC ratio was recorded in the private hybrid Sierra in Salem District.
\end{abstract}

Keywords-Chilli, Capsicum annuum, hybrids, performance, on farm trial

\section{INTRODUCTION}

Salem district was established during 1790 with Mr.Kindarslay as the first Collector. It gave birth to Dharmapuri, Krishnagiri, and Namakkal districts subsequently. The geographical area is $5245 \mathrm{sq}, \mathrm{km}$. Salem district is geologist paradise, surrounded by hills and the landscape dotted with hillocks. It is known for mangoes, silver ornament, textiles, sago industries, and steel production. Salem has got 20 blocks; Average temperature is $32^{\circ} \mathrm{C}$, maximum and 19.6 degree minimum with humidityy ranging from 39 to $85 \%$. During SW monsoon, a rainfall of $545 \mathrm{~mm}$ and during NE monsoon $564.2 \mathrm{~mm}$ was recorded. Net sown area is $22,33,70$ ha and area sown more than once 81670 ha. Area under horticultural crops is 39765 ha and area under chilli cultivation is around 520 ha in Salem District.

Chilli is an important spice cum vegetable crop which is grown throughout India. India is the world's largest producer, consumer and exporter of chillies in the world. The important states of chilli production are Andhra Pradesh, Orissa, Maharashtra, West Bengal, Karnataka, Rajasthan and Tamil Nadu. Chillies are used as an ingredient to add flavour, pungency and colour to most dishes. In Salem district, the area under horticultural crops is 39765 ha and area under chilli cultivation is around 1089 ha in the year 2013-14. Among 20 blocks of Salem district, Kolathur block is well 


\section{International Advanced Research Journal in Science, Engineering and Technology}

Vol. 8, Issue 8, August 2021

DOI: $10.17148 / I A R J S E T .2021 .8880$

known for chilli cultivation in Salem District. Private hybrids are ruling in the market as well as among the farmers though these hybrids show less pungency. Hence. an investigation is needed to assess the performance of high pungent chilli hybrids in Salem district.

\section{EXPERIMENTAL METHODS OR METHODOLOGY}

Chilli is also known as hot pepper or pimento. It is a self pollinated crop and chasmogamous in nature in which flower opens only after pollination. However 2 to $96 \%$ out crossing was observed under open pollination by means of insects (Hasanuzzamman et al. (2012). Chasmogamy is a plant reproductive mechanism in which pollination occurs in chasmogamous flowers (cross-pollinated have the advantage of sexual reproduction between two different parents, resulting in sexual recombination and genetically distinct seeds). Apart from its traditional use, it found its place in pharmceutical industries (due to the presence of Capsaicin) for therapeutic and prophylactic and ayurvedic medicine and processed food industries as source of natural colour extractant (due to the presence of the biochemical Capsanthin) in the food items. It is considered as a vitamin capsule as they are excellent source of vitamin A, C and E (Durust et al. 1997). To meet the high demand of chilli due to increase in population, for increasing the productivity of the crop, hybrids should be considered for cultivation. The hybrid chilli plant yields $61 \%$ higher as compared to open pollinated varieties (Prasad et al. 2019 and Malathi and Veeraragavathatham (2004)).

Hence, this investigation had been carried out to assess the per se performance of high pungent chilli hybrids in Salem district. Primary data was collected on various aspects of chilli cultivation. A field experiment was conducted as an on farm trial in five different locations of Kolathur village in Salem district during Kharif season of 2017 in chilli using hybrids Arka Harita and TNAU Chilli Hybrid CO 1 with Sierra Hybrid of Mahyco (drought and powdery mildew tolerant hybrid with medium pungency fruits of more than $10 \mathrm{~cm}$ long and diameter of 1.1 to $1.3 \mathrm{~cm}$ ) as check hybrid.

\section{RESULTS AND DISCUSSION}

The results (Table 1.) showed that TNAU chilli hybrid CO 1 recorded highest individual fruit weight of $30 \mathrm{~g}$ followed by Arka Harita with individual fruit weight of $28 \mathrm{~g}$. The check hybrid Sierra recorded lesser fruit weight of $23 \mathrm{~g}$. Regarding yield attribute, Arka Harita recorded highest yield per hectare (28.2t/ha) followed by TNAU Chilli Hybrid CO1 (26t/ha) which might be due to the more number of fruits per plant in Arka Harita hybrid. Farmers preference as well as market preference in Salem District is more for TNAU Chilli Hybrid than Arka Harita because of its bigger size fruits with high pungency and high yield. Regarding BC ratio, Arka Harita recorded 2.13 as against 1.97 in TNAU Chilli hybrid CO 1. Least BC ratio was recorded in the private hybrid Sierra in Salem District.

Table 1. Per se performance of different hybrids of chilli in Salem Districts

\begin{tabular}{|l|c|l|l|c|l|l|c|}
\hline $\begin{array}{l}\text { Technology } \\
\text { Option }\end{array}$ & $\begin{array}{l}\text { Plant } \\
\text { height } \\
(\mathbf{c m})\end{array}$ & $\begin{array}{l}\text { Fruit } \\
\text { length } \\
(\mathbf{c m})\end{array}$ & $\begin{array}{l}\text { Fruit } \\
\text { weight }(\mathbf{g})\end{array}$ & $\begin{array}{l}\text { Number } \\
\text { of fruits } \\
\text { per plant }\end{array}$ & $\begin{array}{l}\text { Yield } \\
\text { (green } \\
\text { chilli) (t/ha) }\end{array}$ & $\begin{array}{l}\text { Net } \\
\text { Returns(Rs. in } \\
\text { lakh./ha) }\end{array}$ & B:C ratio \\
\hline $\begin{array}{l}\text { Technology 1 } \\
\text { TNAU Chilli } \\
\text { hybrid CO1 }\end{array}$ & 90 & 10.5 & 28.0 & 205 & 26.0 & 1.54 & 1.97 \\
\hline $\begin{array}{l}\text { Technology 2 } \\
\text { Arka Harita }\end{array}$ & 92 & 9.5 & 23.0 & 218 & 28.2 & 1.24 & 2.13 \\
\hline $\begin{array}{l}\text { Farmers Practice } \\
\text { Sierra hybrid }\end{array}$ & 96 & 11.0 & 30.0 & 188 & 24.5 & 1.36 & 1.86 \\
\hline Mean & 92.57 & 10.3 & 26.99 & 203.9 & 26.27 & & \\
\hline CD5\% & 1.809 & 0.57 & 1.07 & 1.88 & 0.65 & & \\
\hline
\end{tabular}


International Advanced Research Journal in Science, Engineering and Technology

Vol. 8, Issue 8, August 2021

DOI: $10.17148 / I A R J S E T .2021 .8880$

\begin{tabular}{|l|c|c|c|c|c|c|c|}
\hline CD1\% & 2.54 & 0.80 & 1.5 & 2.63 & 0.91 & & \\
\hline SEd & 0.83 & 0.26 & 0.49 & 0.86 & 0.3 & & \\
\hline CV $(\%)$ & 1.68 & 4.77 & 3.41 & 0.79 & 2.92 & & \\
\hline
\end{tabular}

Arka Harita showed profuse flowering and continuous fruit setting character with tolerance to powdery mildew and TNAU Chilli Hybrid CO 1 is moderately resistant to fruit rot disease. Both are high pungent high yielding hybrids.

\section{CONCLUSION}

In Salem District of Tamil Nadu the chilli hybrid namely Arka Harita recorded higher fresh fruit yield of $28.2 \mathrm{t} / \mathrm{ha}$ whereas the TNAU chilli hybrid CO1 recorded an yield of fresh fruits of $26 \mathrm{t} / \mathrm{ha}$. Hence Arka Harita hybrid is suitable for Salem farmers to get higher yield in chilli as well as higher net income and benefit cost ratio.

\section{REFERENCES}

1. Durusut. N.D, Sumengen and Durusut. Y, Ascorbic acid and element content of Trabzon (Turkey), Journal of Agric. Food. Chemistry, vol. 45 , pp. 2085- 2087, 1997.

2. Hassanuzzaman M, Hakkim M.A, Fersdous J, Islam M.M, Rahman L. Combinig ability and heritability analysis for yield and yield attributing characters in chilli landraces. Plant Omics.5(4):337, 2012

3. Malathi. G, and Veeraragavathatham. D, Per se performance and heterosis of two hybrids of chilli (Capsicum annuum L. for qualitative traits in three different seasons. Capsicum and Eggplant Newsletter, vol. 25, pp. 65-68, 2004.

4. Prasad Basavaraj Purad, Usha Nadhini Devi. H, Arumugam. T, and Karthikeyan . M, Growth and performance of different chilli genotypes for yield and yield attributing characters. Journal of Pharmacognosy and Phytochemistry, vol. 8(4), pp. 210-213, 2019. 